\begin{tabular}{|c|c|c|}
\hline institute & $\begin{array}{l}\text { CARADDE: Jurnal Pengabdian Kepada Masyarakat } \\
\text { https://journal.ilininstitute.com/index.php/caradde } \\
\text { Volume 1 | Nomor 1 | Agustus |2018 } \\
\text { e-ISSN: } 2621-7910 \text { dan p-ISSN: } 2621-7961 \\
\text { DOI: https://doi.org/10.31960/caradde.v1i1.18 }\end{array}$ & $\begin{array}{l}\text { IUiN } \\
\text { GARADDE }\end{array}$ \\
\hline
\end{tabular}

\title{
Peningkatan Omset Penjualan Melalui Diversifikasi Produk dan Strategi Promosi Pada UMKM Kerajinan Souvenir Khas Palembang
}

\author{
Siti Khairani ${ }^{1}$, Raisa Pratiwi ${ }^{2}$
}

Keywords :

Peningkatan Penjualan;

Diversifikasi Produk;

Strategi Promosi;

Kerajinan Souvenir

Corespondensi Author

1),2)Akuntansi. STIE Multi

Data Palembang

Jalan Rajawali No 14

Palembang

Email: sitikh@STIE-

MDP.ac.id

\section{History Artikel}

Received: Juni-2018;

Reviewed: Juli-2018

Accepted: Agustus-2018

Published: Agustus-2108

\begin{abstract}
Abstrak. Tujuan dari kegiatan pengabdian ini adalah untuk membantu UMKM Kerajinan Souvenir Khas Palembang dalam meningkatkan penjualan melalui diversifikasi produk dan promosi. Manfaat kegiatan ingin meningkatkan omset penjualan sehingga dapat memperluas jangkauan pemasaran dan meningkatkan pendapatan bagi pemilik usaha kerajinan souvenir. Metode kegiatan dilakukan dengan cara pembinaan, pemberdayaan dan pendampingan melalui pemberian pelatihan-pelatihan, seminar, serta bantuan alat produksi dan promosi. Responden dalam penelitian adalah pemilik usaha kerajinan souvenir khas Palembang milik Ibu Nyayu Nurhayati dan Bapak Yusuf Effendi. Permasalahan yang dihadapi oleh responden adalah mereka masih melakukan jahit manual berupa jahit jelujur tangan pada proses produksi sehingga kualitas dan daya tahan produk kurang baik. Selain itu kreativitas dalam membuat souvenir masih sangat kurang dan belum ada diversifikasi dan diferensiasi produk. Sistem penjualan yang masih menunggu konsumen datang dan belum adanya merek juga menjadi permasalahan responden. Untuk menyelesaikan masalah di atas, maka perlu implementasi untuk meningkatkan jumlah dan jenis kerajinan souvenir melalui diversifikasi produk dan memperluas wilayah pemasaran melalui strategi promosi. Diversifikasi produk dilakukan dengan memberikan pelatihan kerajinan tangan dan menggunakan mesin jahit dalam proses produksi. Sedangkan strategi promosi dilakukan dengan membantu responden untuk aktif menggunakan media sosial seperti fanspage, instagram, dan blog, memanfaatkan marketplace sebagai media penjualan online. Strategi pemerekan (branding) melalui perancangan merek dan ditempatkan pada kemasan, yang bertujuan untuk memperkenalkan merek responden. Hasil dari kegiatan pengabdian masyarakat ini terjadi peningkatan kapasitas produksi hingga mencapai $100 \%$, peningkatan jenis dan kualitas souvenir yang dihasilkan serta meningkatnya omset penjualan sebesar $80 \%$. Hal ini dapat dilihat dari data wawancara awal dan akhir yang telah dilakukan oleh tim pelaksana kegiatan pengabdian. Kesimpulan dari kegiatan ini adanya peningkatan produksi baik jenis dan kualitas souvenir yang dihasilkan, peningkatan media penjualan dan peningkatan omset penjualan serta menguatkan posisi UMKM di era Masyarakat Ekonomi Asean (MEA).
\end{abstract}


Caradde: Jurnal Pengabdian Kepada Masyarakat

Vol 1 No 1, Agustus 2018

\section{PENDAHULUAN}

UMKM merupakan bagian dari industri kreatif, yang merupakan suatu kegiatan usaha yang fokus pada kreasi dan inovasi. Indonesia merupakan Negara yang kaya akan budaya serta tradisi yang bisa menjadi sumber kreativitas. kontribusi ekonomi kreatif terhadap produk domestik bruto (PDB) Indonesia pada 2014 adalah Rp 784,82 triliun dan pada 2015 menjadi Rp 852 triliun atau meningkat 8,6 persen. "Dari total kontribusi tersebut, sub-sektor kuliner, kriya, dan fashion memberikan kontribusi terbesar pada ekonomi kreatif. Sub-sektor kuliner tercatat berkontribusi sebesar 41,69 persen, kemudian fashion sebesar 18,15 persen, dan kriya sebesar 15,70 persen. Selain itu, industri film bertumbuh 10,28 persen, musik 7,26 persen, seni/arsitektur 6,62 persen, dan game tumbuh 6,68 persen. (kompas.id:2017).

Berdasarkan dari data di atas, seharusnya UMKM mendapat perhatian yang serius dari pemerintah dan pihak lainnya agar dapat dibina dan dikembangkan sehingga UMKM mampu menjadi penopang perekonomian Indonesia dan sekaligus memberdayakan masyarakat secara mandiri. Selama ini UMKM kenyataannya masih menghadapi berbagai permasalahan diantaranya lemahnya permodalan dan sulit mengakses sumber modal perbankan, kurangnya pasokan bahan baku (produksi), terbatasnya pemasaran produk, terbatasnya sumber energi, akses informasi, ketersediaan teknik dan keahlian, ketersediaan infrastruktur, kesulitan dalam pembayaran pajak, pengaruh inflasi, dan masalah lingkungan. Akibatnya UMKM sulit berkembang dan tidak mampu bersaing. Oleh karena itu pemerintah melalui instansi terkait perlu melakukan pembinaan dan pengembangan terhadap UMKM (Kasih dan Aprilia, 2014).

Permasalahan-permasalahan di atas merupakan faktor yang menghambat kemajuan UMKM yang berdampak kepada pertumbuhan dan daya saing UMKM.Terlebih lagi dengan pemberlakuan pasar bebas ASEAN tidak menutup kemungkinan akan banyak produk-produk dari UMKM asing yang masuk ke Indonesia . Kondisi ini menjadi tantangan bagi produk
UMKM Indonesia sehingga sangat diperlukan pembinaan, pemberdayaan, dan pendampingan.

Propinsi Sumatera Selatan khususnya di Kota Palembang, mempunyai sentra UMKM yang tersebar di beberapa tempat. Salah satunya adalah UMKM kerajinan souvenir khas Palembang. Sentra UMKM kerajinan souvenir khas Palembang berada di Kelurahan 30 ilir yang juga merupakan pusat pembuatan dan penjualan songket Palembang. Sebagian besar UMKM kerajinan souvenir merupakan usaha rumahan dengan tenaga kerja yang berjumlah kurang lebih dua sampai dengan lima orang. Manajemen usaha masih bersifat sederhana karena belum adanya perencanaan dan pengelolaan keuangan yang baik. UMKM kerajinan souvenir yang menjadi pengamatan penulis adalah usaha kerajinan souvenir milik Ibu Nyayu Nurhayati dan usaha kerajinan souvenir milik Bapak Yusuf Effendi yang sekarang dikelola oleh anak beliau yang bernama Nyayu Rahmawati.

Kerajinan souvenir yang dihasilkan oleh UMKM ini berupa tas, dompet, gantungan kunci, kalung dan lain sebagainya. Dari pengamatan dan analisis situasi , permasalahan yang dihadapi oleh pemilik usaha adalah proses produksi membuat kerajinan khususnya tas dan dompet masih dilakukan dengan jahit manual (jahit jelujur tangan) sehingga kuantitas produksi terbatas , kualitas dan daya tahan pakai produk kurang baik. Desain serta diversifikasi produk yang belum beragam juga menjadi permasalahan UMKM. Saat ini pemilik usaha juga belum menggunakan media promosi untuk memperkenalkan produknya dan hanya menunggu reseller yang datang. Sehingga fokus permasalahan yang dihadapi adalah masalah kuantitas, kualitas, diversifikasi produk dan strategi promosi yang belum optimal.

Berdasarkan analisis situasi di atas, rencana pemecahan masalah yang dilakukan adalah dengan memberikan pelatihan membuat diversifikasi kerajinan souvenir dengan mendatangkan tenaga ahli dari Balitbangda Kota Palembang, Untuk masalah kualitas dan kuantitas souvenir adalah dengan memberikan bantuan alat produksi berupa mesin jahit khusus untuk konveksi. Memberikan pelatihan mengenai strategi 
Caradde: Jurnal Pengabdian Kepada Masyarakat

Vol 1 No 1, Agustus 2018

pemasaran dan promosi produk yang baik untuk menunjang penjualan termasuk penggunaan kantong plastik kemasan bermerek. Dan tujuan akhir dari pengabdian ini diharapkan dapat meningkatkan diversifikasi dan diferensiasiproduk yang dijual dengan kuantitas yag lebih banyak serta kualitas yang lebih baik, merek responden dapat dikenal luas, memperluas jangkauan pemasaran yang pada akhirnya dapat meningkatkan omset penjualan

\section{METODE}

Sifat dari kegiatan ini adalah berbasis kebutuhan dan kemampuan responden, maka metode yang digunakan dalam pelaksanaannya adalah dengan pendekatan partisipatif (partisipative approach) dimana responden terlibat langsung baik dalam FGD (focus group discussion), wawancara, berkonsultasi, dan menentukan keputusan tindakan. Pelaksanaan kegiatan melalui 4 tahapan berikut :

\section{1) Tahap Persiapan dan Perencanaan}

Tim pelaksana melakukan persiapan dan perencanaan dalam bentuk : (a) Sosialisasi Implementasi Pengabdian. Pada tahap ini tim pelaksana akan memaparkan maksud dan tujuan, metode dan teknis pelaksanaan kegiatan, serta melakukan FGD untuk menyepakati prioritas masalah yang dihadapi dan alternatif solusinya. (b) Penyusunan Program Kegiatan. Tim pelaksana melakukan FGD dengan kedua mitra untuk menentukan bentuk, waktu dan tempat pelaksanaan kegiatan. Program kegiatan terdiri dari penyuluhan pentingnya kreativitas dan inovasi produk; pelatihan pemasaran dan promosi usaha;

\section{2) Tahap Implementasi Kegiatan}

Tim pelaksana akan memulai kegiatan sesuai dengan jadwal yang sudah ditentukan dan disepakati bersama dengan responden. Kegiatan pelatihan menggunakan metode ceramah dan diskusi (tanya jawab) sedangkan penentuan keputusan lain berdasarkan hasil FGD dengan responden. Kegiatan pembinaan yang dilaksanakan terdiri dari aspek produksi (pengadaan mesin jahit), aspek keuangan dan permodalan (pelatihan pembukuan usaha, sumber permodalan dan proposal kredit) dan aspek pemasaran dan promosi (pelatihan strategi pemasaran dan penggunaan media promosi)

\section{3) Tahap Evaluasi dan Monitoring}

Kegiatan dimonitoring oleh tim sendiri dan melihat apa saja kendala dan masalah yang muncul di lapangan. Kemudian dilakukan evaluasi apabila memang muncul kendal dan masalah untuk selanjutnya dicarikan solusi agar kegiatan tetap berlangsung dengan baik sesuai yang diharapkan. Metode yang digunakan adalah FGD dengan responden.

\section{4) Tahap Refleksi}

Refleksi terhadap hasil pelaksanaan kegiatan dilakukan dengan tujuan untuk memperoleh umpan balik terhadap manfaat maupun dampak yang dirasakan mitra setelah dilakukan pelatihan dan pembinaan. Hal ini diperlukan sebagai masukan bagi pelaksanaan kegiatan serupa di masa datang. Metode yang digunakan adalah FGD dengan responden

\section{HASIL DAN PEMBAHASAN}

\section{Pemasaran Terintegrasi}

Pemasaran merupakan salah satu bagian terpenting bagi sebuah usaha. Sebuah usaha yang berhasil adalah mampu merencanakan aktivitas pemasaran dan membentuk program pemasaran yang terintegrasi..Aktvitas pemasaran yang dimaksud adalah bauran pemasaran (marketing mix) yang terdiri dari variabel produk (product), harga (price), tempat (place) dan promosi (promotion) (Kotler dan Keller, 2009). Dari hasil wawancara dan pengamatan di lokasi bahwa permasalahan yang dihadapi oleh pemilik usaha adalah sulit menjual produk, standarisasidan diversifikasi produk belum ada karena sebagian besar kerajinan yang dihasilkan sama dengan pesaing, serta tidak adanya strategi promosi. Untuk itu maka bagian selanjutnya akan diuraikan strategi untuk meningkatkan daya saing dan pengembangan usaha responden yaitu strategi produk (product) dan promosi (promotion) sehingga dapat meningkatkan omset penjualan.

\section{Strategi Produk}


Khairani, Pratiwi. Peningkatan Omset penjualan

Kerajinan souvenir khas Palembang yang saat ini diproduksi dan dijual oleh pemik usaha terdiri dari tas, dompet, gantungan kunci dan kalung yang semuanya menggunakan corak kain songket dan jumputan. Usaha kerajinan seperti ini sangat banyak dan secara umum sama, maka strategi diversifikasi dan diferensiasi pada usaha ini sangatlah penting. Diversifikasi adalah usaha penganekaragaman produk. Pengane-karagaman produk akan menghasilkan perbedaan produk dari pesaing. Melalui diversifikasi produk diharapkan dapat memaksimalkan omset penjualan. Diversifikasi yang tepat dilakukan melalui peningkatan kualitas produk. Kualitas produk dapat ditingkatkan dengan mengikuti pelatihan membuat kerajinan tangan oleh tenaga ahli yang berkompeten dibidangnya. (Sarwoko, Surrachman, Djumillah: 2013). Tim pelaksana pengabdian mengundang Komunitas UMKM Kota Palembang di bawah naungan Balitbangda sebagai instruktur pelatihan. . Proses penjahitan tas ataupun dompet yang awalnya hanya jahit jelujur tangan diganti dengan jahit mesin sehingga hasil yang didapat akan lebih banyak dan kualitas lebih baik. Diversifikasi yang telah dilakukan untuk usaha responden adalah membuat cover agenda dan hiasan bunga tulip. Keunggulan hasil kerajinan ini dibandingkan dengan produk lain yang sejenis adalah menggunakan kain songket sebagai bahan utama pembuatan cover dan bunga tulip yang merupakan ciri khas Kota Palembang sebagai Kota Songket selain juga dikenal sebagai Kota Pempek. Melalui pelatihan diversifikasi dan diferensiasi produk dapat membantu pemilik usaha dalam menemukan ide baru atau design baru untuk kerajinan Palembang dan diharapkan dua produk ini dapat menambah daya tarik pembeli karena hasilnya unik dan untuk di sentra industri kerajinan wilayah 30 ilir belum ada pengrajin yang membuatnya. Diversifikasi produk yang telah dilakukan adalah seperti gambar berikut:
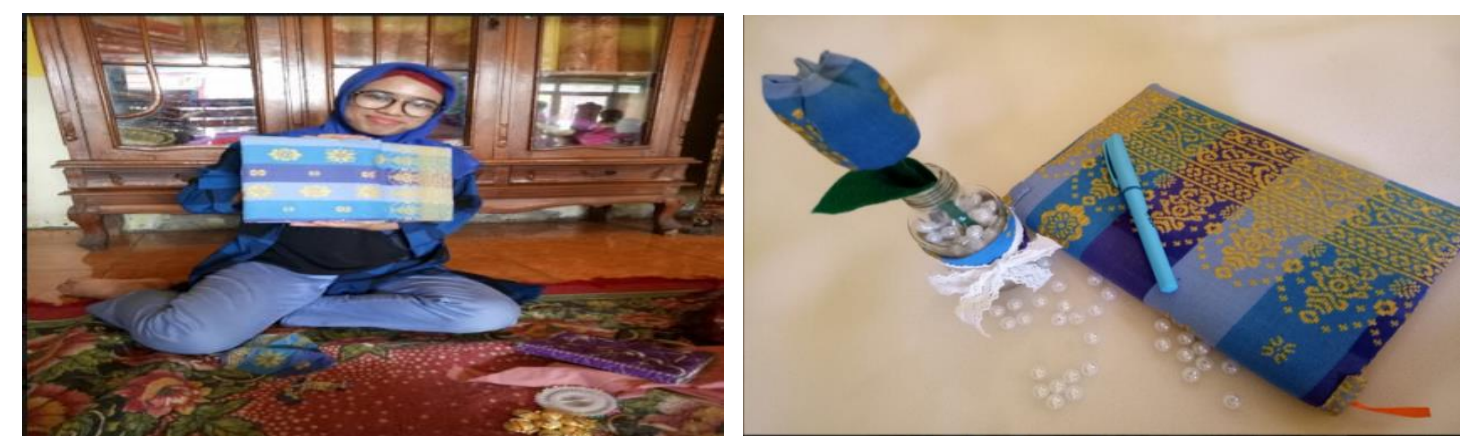

Gambar 1. Diversifikasi produk berupa cover agenda dan hiasan bunga tulip
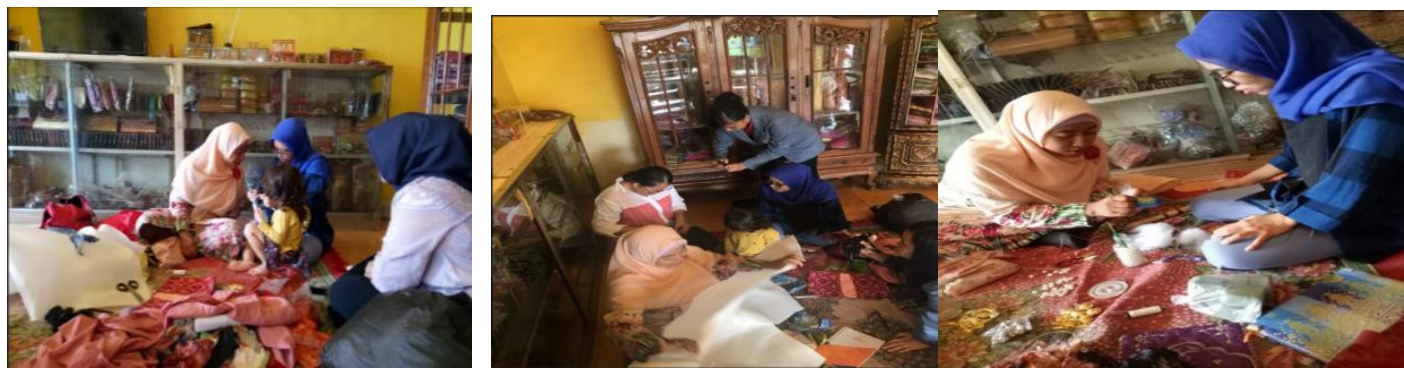

Gambar 2. Foto Kegiatan Pelatihan Membuat Cover agenda \& Hiasan Bunga Tulip

Dari pelatihan di atas telah menumbuhkan ide kreativitas dan inovasi responden untuk membuat aneka macam kerajinan souvenir lainnya. Berikut tabel kapasitas produksi dan jenis kerajinan souvenir sebelum dan sesudah dilakukan pelatihan. 
Caradde: Jurnal Pengabdian Kepada Masyarakat

Vol 1 No 1, Agustus 2018

Tabel 1. Kapasitas Produksi dan Jenis

Kerajinan Souvenir Per Hari Milik

Ibu Nyayu Nurhayati

\begin{tabular}{lllll}
\hline $\begin{array}{c}\text { N } \\
\text { o }\end{array}$ & \multicolumn{2}{c}{$\begin{array}{c}\text { Sebelum Ada } \\
\text { Pelatihan }\end{array}$} & \multicolumn{2}{c}{$\begin{array}{c}\text { Sesudah Ada } \\
\text { Pelatihan }\end{array}$} \\
\hline & $\begin{array}{c}\text { Jenis } \\
\text { Souveni } \\
\end{array}$ & $\begin{array}{c}\text { Kapasit } \\
\text { as } \\
\text { Produk } \\
\text { si }\end{array}$ & $\begin{array}{c}\text { Jenis } \\
\text { Souveni } \\
\text { r }\end{array}$ & $\begin{array}{c}\text { Kapasit } \\
\text { as } \\
\text { Produk } \\
\text { si }\end{array}$ \\
\hline 1 & Tas & 2 buah & Tas & 4 buah \\
& Purun & & Purun & \\
\hline 2 & Dompet & 3 buah & Dompet & 8 buah \\
\hline 3 & Gantung & 5 & Gantung & 10 \\
& an & & an Kunci & buah \\
& Kunci\& & & & \\
& Kalung & & & \\
\hline 3 & Cover & Belum & Cover & 8 buah \\
& Agenda & ada & Agenda & \\
\hline 4 & Bunga & Belum & Bunga & 12 \\
& Tulip & ada & Tulip & buah \\
\hline 5 & Tas & Belum & Tas & 8 buah \\
& Jumputa & ada & Jumputa & \\
& n & & $n$ & \\
\hline 6 & Pouch & Belum & Pouch & 12 \\
& Serba & ada & Serba & buah \\
& Guna & & Guna & \\
\hline
\end{tabular}

Berdasarkan data di atas dapat dilihat selain adanya peningkatan kapasitas produksi yang mencapai hampir $100 \%$ juga adanya peningkatan keanekaragaman souvenir antara lain berupa cover agenda, hiasan bunga tulip, tas jumputan dan pouch serba guna. Peningkatan tersebut dapat meningkatkan omset penjualan rata-rata sebesar $80 \%$, yang mana sebelumnya omset penjualan hanya sebesar Rp 450.000 per minggu sekarang bisa mencapai Rp 800.000 - Rp 900.000 per minggu. Penjualan dari toko online (instagram dan shopee) sekitar $25 \%$ dan sisanya $55 \%$ dari penjualan offline (hasil wawancara di lapangan, 2018)

Strategi pemerekan (branding) dapat disinergikan dengan strategi produk. Merek merupakan suatu nama, simbol, istilah atau design yang digunakan untuk mengidentifikasikan produk dan membedakan produk perusahaan dengan produk pesaing. Pemilihan nama merek yang tepat merupakan keputusan penting. Beberapa hal yang harus dipertimbangkan untuk membentuk nama
Tabel 2.Kapasitas Produksi dan Jenis Kerajinan Souvenir Per Hari Milik Ibu Nyayu Rahmawati

\begin{tabular}{|c|c|c|c|c|}
\hline \multirow[t]{2}{*}{$\begin{array}{l}\mathbf{N} \\
\mathbf{o}\end{array}$} & \multicolumn{2}{|c|}{$\begin{array}{c}\text { Sebelum Ada } \\
\text { Pelatihan }\end{array}$} & \multicolumn{2}{|c|}{$\begin{array}{l}\text { Sesudah Ada } \\
\text { Pelatihan }\end{array}$} \\
\hline & $\begin{array}{l}\text { Jenis } \\
\text { Souveni } \\
\quad \mathbf{r}\end{array}$ & $\begin{array}{c}\text { Kapasit } \\
\text { as } \\
\text { Produk } \\
\text { si }\end{array}$ & $\begin{array}{l}\text { Jenis } \\
\text { Souveni } \\
\quad \mathbf{r}\end{array}$ & $\begin{array}{l}\text { Kapasit } \\
\text { as } \\
\text { Produk } \\
\text { si }\end{array}$ \\
\hline 1 & Dompet & 4 buah & Dompet & $\begin{array}{l}10 \\
\text { buah }\end{array}$ \\
\hline 2 & $\begin{array}{l}\text { Gantung } \\
\text { an Kunci }\end{array}$ & 10 buah & $\begin{array}{l}\text { Gantung } \\
\text { an Kunci }\end{array}$ & $\begin{array}{l}12 \\
\text { buah }\end{array}$ \\
\hline 3 & $\begin{array}{l}\text { Cover } \\
\text { Agenda }\end{array}$ & $\begin{array}{l}\text { Belum } \\
\text { ada }\end{array}$ & $\begin{array}{l}\text { Cover } \\
\text { Agenda }\end{array}$ & $\begin{array}{l}10 \\
\text { buah }\end{array}$ \\
\hline 3 & $\begin{array}{l}\text { Bunga } \\
\text { Tulip }\end{array}$ & $\begin{array}{l}\text { Belum } \\
\text { ada }\end{array}$ & $\begin{array}{l}\text { Bunga } \\
\text { Tulip }\end{array}$ & $\begin{array}{l}10 \\
\text { buah }\end{array}$ \\
\hline 4 & $\begin{array}{l}\text { Tas } \\
\text { Mukena }\end{array}$ & $\begin{array}{l}\text { Belum } \\
\text { ada }\end{array}$ & $\begin{array}{l}\text { Tas } \\
\text { Mukena }\end{array}$ & $\begin{array}{l}10 \\
\text { buah }\end{array}$ \\
\hline 5 & $\begin{array}{l}\text { Tas } \\
\text { Serut }\end{array}$ & $\begin{array}{l}\text { Belum } \\
\text { ada }\end{array}$ & $\begin{array}{l}\text { Tas } \\
\text { Serut }\end{array}$ & $\begin{array}{l}10 \\
\text { buah }\end{array}$ \\
\hline 6 & $\begin{array}{l}\text { Pouch } \\
\text { Serba } \\
\text { Guna } \\
\end{array}$ & $\begin{array}{l}\text { Belum } \\
\text { ada }\end{array}$ & $\begin{array}{l}\text { Pouch } \\
\text { Serba } \\
\text { Guna } \\
\end{array}$ & $\begin{array}{l}12 \\
\text { buah }\end{array}$ \\
\hline 7 & $\begin{array}{l}\text { Peci/ } \\
\text { Kopiah }\end{array}$ & $\begin{array}{l}\text { Belum } \\
\text { ada }\end{array}$ & $\begin{array}{l}\text { Peci/ } \\
\text { Kopiah }\end{array}$ & 5 buah \\
\hline
\end{tabular}

merek yang bagus adalah perbedaan merek dari penawaran pesaing, mampu menciptakan asosiasi yang baik, kuat dan mungkin unik, mampu mencapai kesesuaian dengan rancangan dan kemasan serta citra merek yang diinginkan serta mudah diingat dan diucapkan(Shimp, 2014). Merek kerajinan songket biasa menggunakan nama pemilik, dengan pertimbangan mudah diingat dan diucapkan. Usaha kerajinan souvenir milik Ibu Nyayu Nurhayati memiliki merek Cantik Manis Songket By Santi, dipilih dari nama pemiliknya. Sedangkan Pak Yusuf memilih merek Yusuf Effendi Songket, dipilih karena Pak Yusuf sudah dikenal masyarakat setempat.

Hal lain yang berkaitan dengan nama merek adalah logo merek (brand mark). Desain logo yang baik adalah dapat dikenal baik, mampu menyampaikan makna yang sama untuk semua anggota target dan menimbulkan perasaan positif (Shimp, 2014). Tim penulis membantu merancang logo dan kemasan responden seperti gambar berikut. 


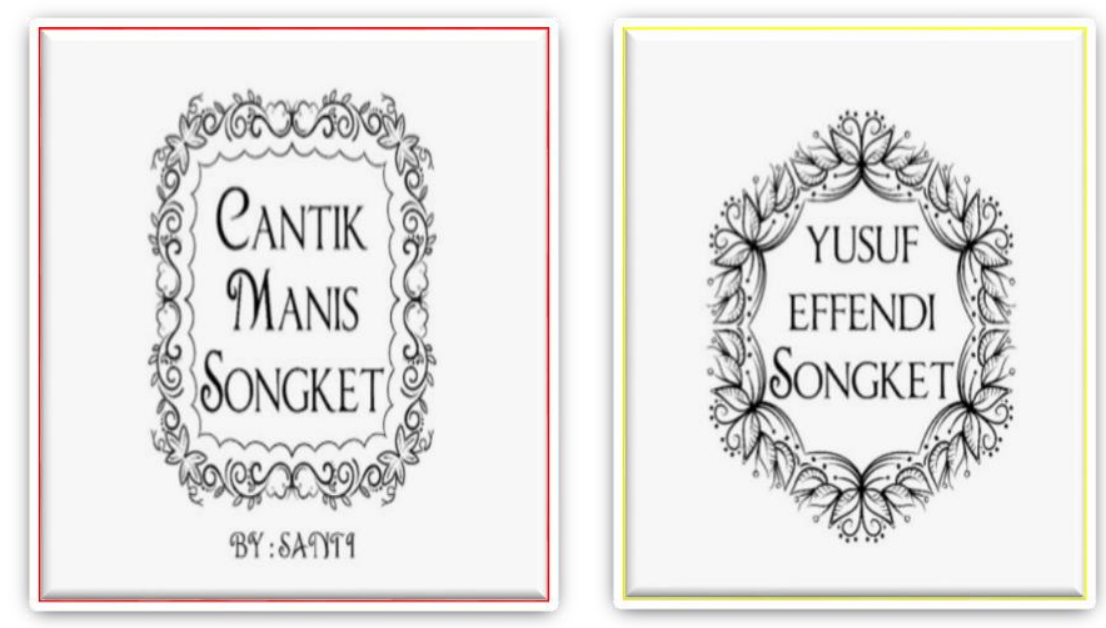

Gambar 2. Merek dan Logo Kerajinan Souvenir

Logo merek souvenir akan disablon pada kantong plastik kemasan. Logo merek sengaja tidak dibuat banyak ornamen dengan pertimbangan kerajinan songket adalah kerajinan khas Palembang yang terkesan elegan, sehingga logo yang dibuatpun harus terkesan elegan.

\section{Strategi Promosi}

Strategi promosi bertujuan dalam peningkatan volume penjualan. Kesesuaian minat konsumen dengan konten promosi yang dijalankan akan menimbulkan permintaan terhadap suatu produk. Peningkatan permintaan inilah yang akan mendorong proses produksi yang diakibatkan adanya kenaikan penjualan. Indikator strategi promosi yang jitu dapat dilihat dari peningkatan volume penjualan setelahnya.Strategi promosi adalah mengacu pada semua bentuk dasar dari komunikasi pemasaran meliputi media massa tradisional (televisi, majalah,dsb), iklan online (Situs, pesan surat elektronik, sms, dsb), promosi penjualan (sampel, kupon,rabat, barang-barang premium, dsb), public relations dan iklan rilis, sponsorship acara-acara, presentasi bagian penjualan dan berbagai bentuk jaminan sebagai sarana komunikasi (Shimp, 2014). Strategi promosi merupakan berbagai sarana dan media komunikasi yang terintegrasi dalam bauran pemasaran (marketing mix) (Lestari, Widagdo, dan Ayu: 2016)

Pemilik usaha saat ini belum menggunakan strategi promosi dan hanya mengandalkan komunikasi dari mulut ke mulut dan terkadang tidak setiap tahun mengikuti pameran kerajinan Palembang. Keputusan pemilihan media promosi harus mempertimbangkan beberapa faktor antara lain segmen pasar yang dituju, anggaran yang tesedia dan tujuan strategi promosi. Walaupun skala usaha kerajinan Palembang tergolong usaha kecil, namun harus tetap memerlukan strategi promosi, yang bertujuan untuk membangun kesadaran merek, memberikan informasi, membujuk, membangun sikap atau maksud pembelian merek yang pada akhirnya dapat menambah omset penjualan. (Kotler dan Keller, 2009)

Responden sebagai pemilik usaha kerajinan souvenir Palembang belum melalukan strategi promosi yang signifikan. Belum banyak media promosi online yang dapat dimanfaatkan oleh pemilik usaha. Dengan memanfaatkan media promosi online pemilik usaha dapat memperluas jangkauan wilayah pemasaran tidak hanya di daerah sekatar saja tapi bisa memperluas wilayah pemasaran sampai ke luar wilayah Sumatera Selatan. Komunikasi pemasaran modern selalu mengikuti perkembangan teknologi, memanfaatkan jaringan digital internet, diintegrasikan dan digabungkan dengan komunikasi pemasaran tradisional. Untuk itu tim pengabdian memberikan pelatihan cara membuat fanspage, dan blog sebagai media promosi. Kemajuan teknologi informasi sebagai media promosi cukup efisien untuk pengembangan usaha dan daya saing dengan melalui : (a) Media Sosial, pilihan media sosial yang dapat digunakan adalah fanspage, instagramdan blogdengan jumlah pengguna 
lebih banyak dibandingkan media sosial lain. Keuntungan mempromosikan produk melalui media sosial adalah lebih efisien karena tidak berbayar dan memungkinkan penyebaran berita dari mulut ke mulut yang lebih cepat. Jangkauan media sosial juga sangat luas. Oleh karena itu tim penulis membantu untuk membuat akun fanspage dan blog sebagai strategi promosi, (b) Social market place. merupakan model bisnis dimana website yang bersangkutan tidak hanya membantu mempromosikan barang dagangan saja, tapi juga memfasilitasi transaksi uang secara online. Pada sistem belanja online ini, sebuah website menyediakan lahan atau tempat bagi para penjual untuk menjual produk-produknya. Contoh marketplace adalah shopee.co.id, tokopedia.com, buka lapak.com, olx.co.id. Pemilik usaha menawarkan produknya melalui market placeshopee dengan pertimbangan shopee merupakan social market place yang paling banyak dikunjungi oleh konsumen. Shopee.co.id merupakan salah satu situs online marketplace terbesar dan termurah di Indonesia. Berdasarkan data, shopee berada pada peringkat ke enam setalah mataharimall.com (Liputan6: 2017). Berikut adala foto media promosi yang dimiliki oleh pemilik usaha setelah dilakukan pelatihan.
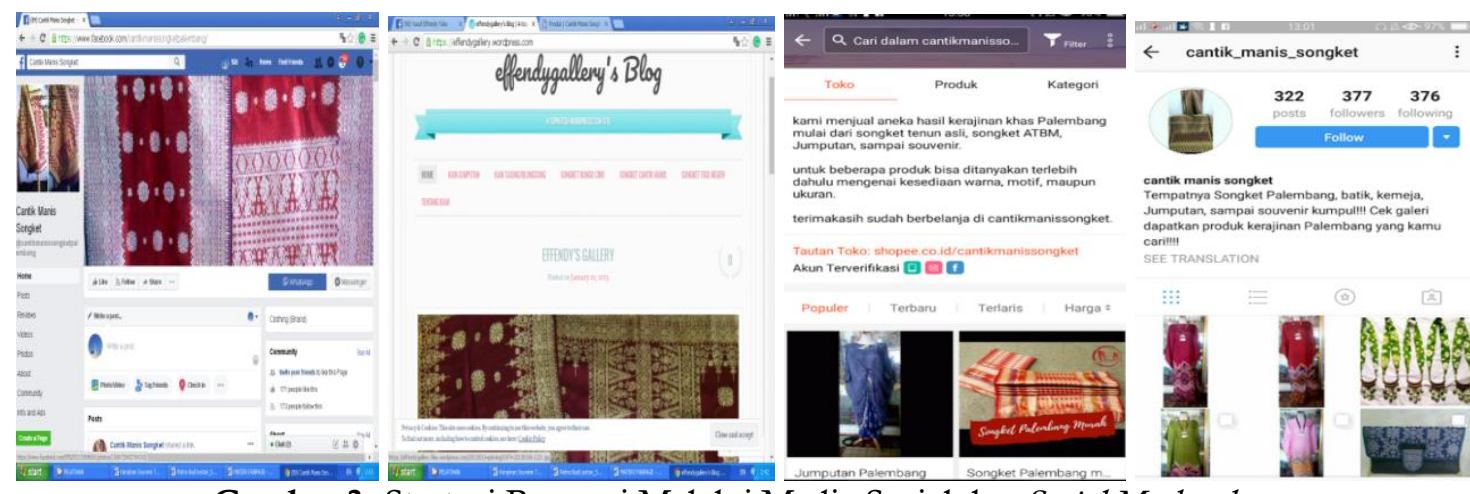

Gambar 3. Strategi Promosi Melalui Media Sosial dan Social Marketplace
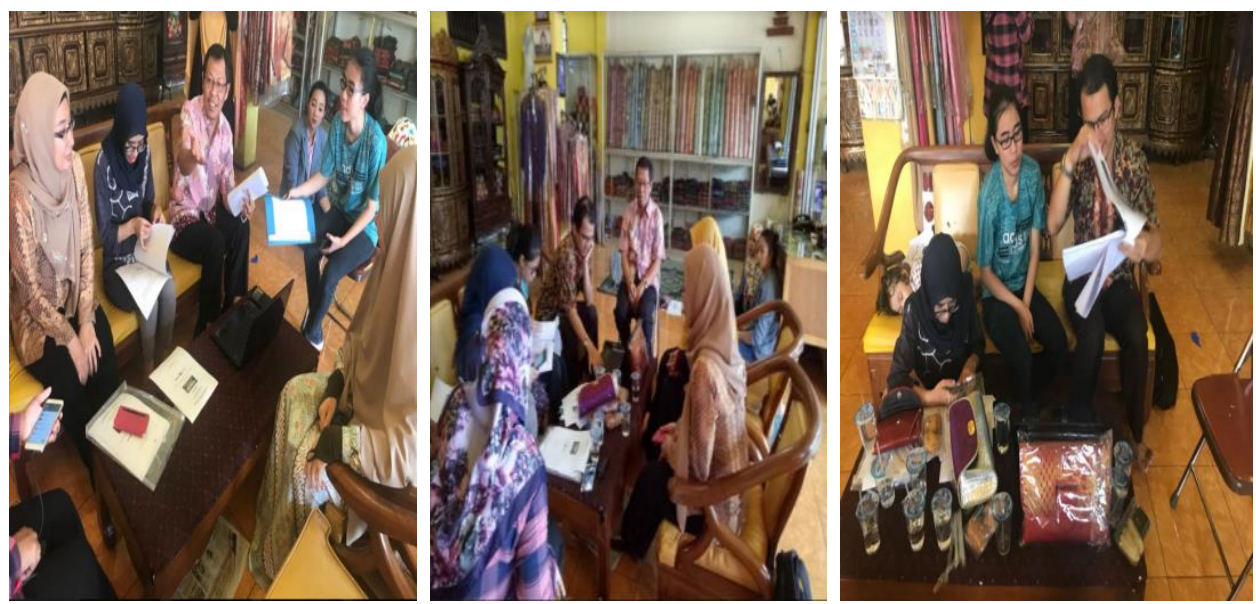

Gambar4. Foto Kegiatan PelatihanStrategi Promosi Melalui Media Sosial dan Social Marketplace

Papan Nama Usaha. merupakan sebuah media informasi yang berisi nama perusahaan.Manfaat papan nama sebagai media komunikasi bisnis menjadi faktor penting kesuksesan menginformasikan brand perusahaan.Papan nama usaha bisa berfungsi sebagai media jalan pintas untuk mengundang pengunjung untuk membeli dan memakai produk yang ditawarkan atau dijual. Saat ini pemilik usaha sudah mempunyai papan nama usaha hanya saja papan nama yang dimiliki ukurannya kecil dan kurang menarik untuk dilihat. Untuk itu tim pengabdian membuatkan papan nama usaha dengan ukuran yang lebih besar, design yang simple dan menarik perhatian pembeli. Harapannya dengan adanya pembaruan papan nama dapat menambah jumlah pengujung dan pembeli di 
tempat pemilik usaha serta dapat meningkatkan penjualan.
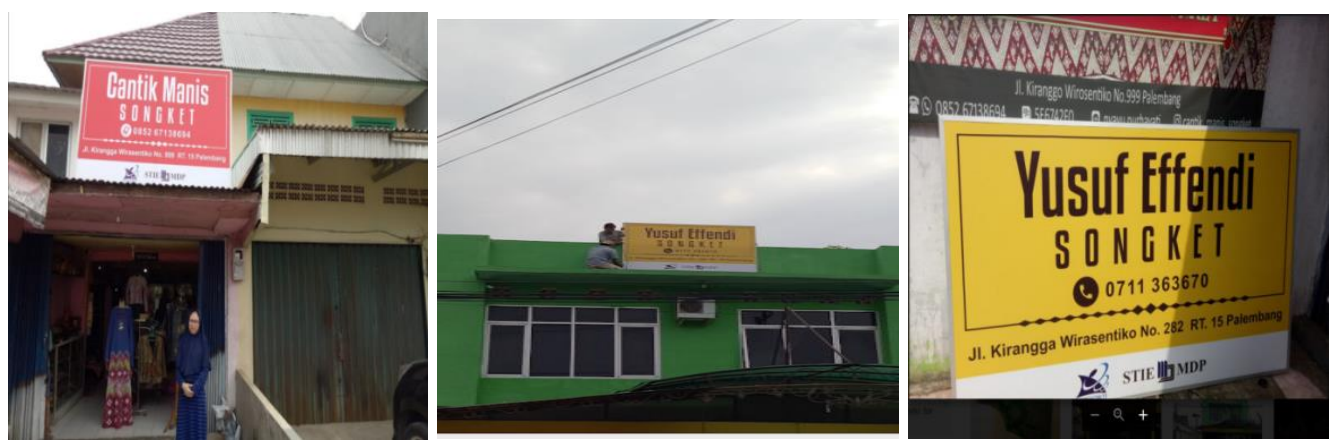

Gambar 5. Papan Nama Usaha

\section{SIMPULAN DAN SARAN}

Kesimpulan dari kegiatan pengabdian ini antara lain adanya diversifikasi dan differensiasi produk kerajinan souvenir, peningkatan omset penjualan, penambahan alat penunjang produksi berupa dan promosi serta peningkatan promosi yang cukup efisien melalui media - media sosial antara lain instagram, fanspage,blog dan marketplace shopee. Strategi produk dan promosi yang diimplementasikan pada artikel ini dapat menjadi alternatif solusi untuk mengangkat UKM khas Palembang agar dapat bersaing serta memperluas jangkauan pasarnya. Pemerintah diharapkan dapat menjadi fasilitator dalam upaya mengembangkan UKM dengan berbagai bentuk pembinaan bekerjasama dengan dinas yang terkait. Sehingga dapat menguatkan posisi UMKM di era Masyarakat Ekonomi Asean (MEA)

\section{DAFTAR RUJUKAN}

Anonim. (2017, 23 NOV). "Kontribusi Ekonomi Kreatif terhadap PDB Indonesia". Diperoleh tanggal 31 Juli 2018 dari (https://kompas.id/baca/adv_post/ko ntribusi-ekonomi-kreatif-terhadap-pdbindonesia/).
Kasih. Y, dan Aprillia. R. 2014. The Competitiveness of Indonesian MicroSmall-Medium Enterprises (MSMEs) Facing ASEAN Economic Community (AEC) in 2015 . International Conference on Economic and Information System Management. Page. 155-163. https://scholar.google.co.id/citations ?user $=$ g2ae91gAAAAJ\&hl=en

Kotler, Philip dan Kevin Lane Keller. 2009. Manajemen Pemasaran Jilid I dan II. Erlangga, Jakarta. Hal. 24

Lestari, R.B, Widagdo, H, dan Ayu, C. 2016. Peningkatan Daya Saing Melalui Strategi Produk dan Promosi Pada UKMK Kerupuk Kemplang di Seberang Ulu I Palembang. Seminar Nasional Penelitian dan Pengabdian Pada Masyarakat, AVoer 8. Fakultas Teknik Universitas Sriwijaya. Hal. 111

Librianty Andina. (2017, 23 AGUSTUS). "Ini 10 Toko Online Terbaik di Indonesia " diperoleh tanggal 31 Juli 2018. Dari : https://www.liputan6.com/tekno/rea d/3068210/ini-10-toko-online-terbaikdi-indonesia

Sarwoko, E. Surachman,.A. dan Djumilah H.2013. Entrepreneurial

Characteristics and Competency as Determinan of Business Performance in SMEs. IOSR journal of Business and Management. Page. 33

http://www.iosrjournals.org/iosr$\mathrm{jbm} /$ papers/Vol7issue3/E0733138.pdf 
Caradde: Jurnal Pengabdian Kepada Masyarakat Vol 1 No 1, Agustus 2018

Shimp. A Terence. 2014. Komunikasi Pemasaran Terpadu.Salemba Empat, Jakarta. Hal: 48 